\title{
Memeriksa Hubungan Customer Brand Dalam Komunitas Brand Platform Media Sosial Produk Nature Republic
}

\author{
Rani Roslaeni \\ Universitas Esa Unggul \\ Jl. Arjuna utara No. 9, Kebon Jeruk, Jakarta Barat \\ e-mail: roslaenirani@gmail.com
}

\begin{tabular}{lll}
\hline Informasi Artikel Diterima: 18-05-2021 & Direvisi: 15-07-2021 & Disetujui: 21-07-2021 \\
\hline
\end{tabular}

\begin{abstract}
Abstrak
Perkembangan industri kosmetik di Indonesia yang sedang berkembang pesat saat ini baik produk lokal maupun impor, terutama pada produk make up dan skincare, sehingga menyebabkan persaingan yang sangat ketat antar perusahaan menjadi lebih bersaing. Strategi yang digunakan oleh Nature Republic dengan membentuk kekuatan merek dan memberikan dan meningkatkan kepercayaan brand yang positif kepada pelanggan. Penelitian ini memiliki tujuan untuk mengetahui pengaruh customer brand terhadap variable loyalitas brand dan WOM (word of mouth) dengan dimediasi oleh variable kepercayaan brand, sehingga dapat mengetahui apakah ada pengaruh pelanggan tersebut menjadi loyal dan percaya terhadap produk Nature Republic. Penelitian ini menggunakan komunitas brand konsumen produk Nature Republic di platform media social yang berada di wilayah Jakarta Barat. Metode pengumpulan data dilakukan dengan menyebar kuisioner melalui media google form kepada setiap konsumen yang menggunakan produk Nature Republic. Jenis penelitian yang digunakan dalam penelitian ini kuantitatif deskriptif dengan mengumpulkan dan menganalisis data 195 responden dari pelanggan yang menggunakan produk Nature Republic kemudian mengolah data tersebut menggunakan analisis Structural Equation Modeling (SEM). Hasil penelitian menyatakan bahwa dengan menggunakan mediasi kepercayaan brand ternyata hasilnya berpengaruh positif terhadap customer brand, loyalitas dan Word of Mouth (WOM) yaitu dengan nilai T-Value berturut-turut $0.61,2.50,1.98,1.83,3.24,2.89$. Meskipun ada beberapa data kuisioner yang tidak bisa digunakan dalam analisa hipotesis ini namun data yang tersedia tetap dapat mewakili hasil hipotesis yang dibutuhkan dalam pengujian hipotesis, sehingga peneliti menyimpulkan dari semua data penelitian yang disajikan bahwa semakin tingginya kepercayaan brand produk Nature Republic akan meningkatkan penjualan dari produk tersebut.
\end{abstract}

Kata Kunci: Kepercayaan brand, Loyalitas brand, WOM, customer brand

Abstract

The development of the cosmetic industry in Indonesia, which is currently growing rapidly, both local and imported products, especially cosmetic and skin care products, has caused intense competition between companies to become more competitive. The strategy used by Nature Republic is to build brand strength and provide and increase positive brand trust to customers. This study aims to determine the effect of the customer's brand on the variable brand loyalty and WOM (word of mouth) mediated by the brand trust variable, so as to determine whether there is an influence the customer becomes loyal and believes in Nature Republic products. This study uses the Nature Republic product consumer brand community on social media platforms located in the West Jakarta area. The data collection method is done by distributing questionnaires through the google form media to every consumer who uses Nature Republic products. The type of research used in quantitative descriptive research is to collect and analyze data from 195 respondents from customers who use Nature Republic products and then process the data using Structural Equation Modeling (SEM) analysis. The results of the study indicate that by using brand trust mediation, the results have a positive effect on customer brand, loyalti and Word of Mouth (WOM) with T-Value values of 0.61, 2.50, 1.98, 1.83, 3.24, 2.89 respectively. Although there are some questionnaire data that cannot be used in hypothesis analysis, the available data can represent the results of the hypotheses needed in testing, so the researchers conclude from all the research data presented that the higher the trust in the Nature Republic product brand will increase sales of these products.

Keywords: Brand trust, Brand Loyalty, WOM, Customer brand

This work is licensed under a Creative Commons Attribution-ShareAlike 4.0 International License. 


\section{Pendahuluan}

Kosmetik memiliki peranan yang sangat penting dalam memenuhi kebutuhan nutrisi pada kulit. Sektor industry kosmetik dan perawatan kulit mengalami peningkatan pertumbuhan $7 \%$ disepanjang tahun 2019, dan kementerian perindustrian menargetkan pertumbuhan industry kosmetik diatas 9\% ditahun 2020 (Kemenperin: Perubahan Gaya Hidup Dorong Industri Kosmetik, n.d.). Dalam memajukan industry kosmetik setiap perusahaan memiliki strategi dalam pemasarannya. Perkembangan jaman yang semakin canggih merupakan peluang yang sangat baik bagi perusahaan dalam melakukan komunikasi dengan pelanggan (Aladwani, 2014). Jumlah penduduk sekitar 270,20 juta jiwa yang menjadikan Indonesia pasar yang menjanjikan bagi perusahaan kosmetik (Badan Pusat Statistik, n.d.). Kosmetik yang berkembang pesat di Indonesia tidak hanya kosmetik dalam negeri namun juga kosmetik impor sehingga muncul berbagai brand dan jenis produk kosmetik di Indonesia (Kemenperin: Industri Kosmetik Nasional Tumbuh 20\%, n.d.). Dalam memenang persaingan ini setiap perusahaan memiliki strategi yang dipilih untuk mencapai sasaran yang diharapkan.

Media sosial yang saat ini paling popular platform termasuk Facebook, Twitter dan YouTube (Nisar \& Whitehead, 2016). Menurut (Rapp \& Beitelspacher, 2013), sekitar 88 persen perusahaan termasuk media, IT dan telekomunikasi, FMCG dan ritel, perjalanan dan liburan telah dimulai untuk menggunakan berbagai platform media sosial dan diantaranya sekitar 42 persen telah sepenuhnya memasukan berbagai situs media sosial kedalam strategi pemasaran brand. Media sosial merupakan cara yang lebih efisien untuk menemukan pelanggan baru dan mempertahankan pelanggan yang ada (Luo et al., 2015). Beberapa penelitian mengungkap bahwa komunikasi brand dapat memiliki pengaruh yang kuat pada kepercayaan brand dan loyalitas brand melalui citra brand. Nature Republic memiliki citra brand dan reputasi yang baik hal ini memungkinkan pelanggan akan cenderung percaya dan lebih setia (Chinomona, 2016). Hasil penelitian Dwi Karyati, 2019 mengungkapkan bahwa citra brand Nature Republic 78,38\% yang termasuk dalam kategori baik. Dalam studi penelitian Examining consumerbrand relationships on social media platforms yang dilakukan Jain et al., 2018 di wilayah ibukota Utara India mengungkapkan bahwa kepercayaan brand sebagian dimediasi antara variabel keterlibatan dan komitmen hubungan pelanggan brand dan loyalitas brand dan word of mouth (WOM). Namun, hubungan antara variable kepuasan hubungan pelanggan brand, loyalitas brand dan dari mulut ke mulut melalui kepercayaan brand ditemukan tidak signifikan (Jain et al., 2018). Dari informasi data penelitian Jain et al., 2018 peneliti bermaksud meneliti dan menyelidiki variabel tersebut dengan menggunakan subjek produk Nature Republic tanpa menggunakan variabel kepuasan pelanggan ini, apakah dengan variabel kepercayaan brand sebagai mediasi antara variabel keterlibatan pelanggan dan komitmen pelanggan akan berpengaruh positif terhadap loyalitas brand dan word of mouth (WOM) dalam komunitas brand platform media sosial produk Nature Republic. Karena itu peneliti melakukan penelitian terhadap komunitas brand masyarakat yang ada diwilayah Jakarta Barat yang menggunakan produk Nature Republic. Hal yang akan dilakukan untuk mengungkap pertanyaan penelitian sebagai berikut:

- Apakah dengan variabel kepercayaan brand sebagian dimediasi antara variabel keterlibatan dan komitmen pelanggan brand berhubungan positif dengan loyalitas brand dan word of mouth (WOM) dalam komunitas brand platform media sosial Nature Republic.

Dari pertanyaan ini peneliti berharap adanya manfaat yang diperoleh sehingga akan mendorong konsumen untuk melakukan tindakan. Apabila terdapat dampak yang positif maka konsumen akan loyal dan dapat mempengaruhi orang lain untuk mencoba dan melakukan pembelian terhadap produk tersebut. Dan apabila dampaknya kurang maka konsumen tidak akan loyal dan cenderung untuk melakukan pilihan alternative lain atau melakukan pembelian pada produk lainnya. Berdasarkan fenomena tersebut, maka penulis ingin membahas lebih lanjut implementasi kepercayaan brand yang dilakukan oleh komunitas brand Nature Republic yang berjudul Memeriksa Hubungan customer brand dalam komunitas brand platform media social produk Nature Republic.

\section{Tinjauan Pustaka \\ Keterlibatan Pelanggan (KP)}

Keterlibatan dianggap sebagai komponen kunci yang memfasilitasi hubungan pelanggan (S. H. Kim \& Lee, 2017). Keterlibatan didefinisikan sebagai "relevansi yang dirasakan dari objek berdasarkan kebutuhan, nilai, dan kepentingan yang melekat" (Users, n.d.). Keterlibatan bukanlah hubungan yang aktif, biasanya membutuhkan beberapa objek konsumsi (Mollen \& Wilson, 2010), dan itu terutama didasarkan pada kasih sayang atau motivasi, kognisi (Lisle, 2016) tetapi sebenarnya tidak pada perilaku (Users, n.d.). Keterlibatan pelanggan sangat penting dalam menganalisa dan menjelaskan perilaku konsumen. Tingkat keterlibatan konsumen dapat mempengaruhi keputusan pembelian dan didiskusikan oleh teori perilaku ketika membahas masalah loyalitas brand (Bennett et al., 2005). Menurut Laurent \& Kapferer 1985 mengkonseptualisasikan keterlibatan konsumen sebagai konstruksi multidimensi yang terdiri dari lima faktor penentu yaitu makna pribadi dan referensi-diri, kemampuan untuk memberikan 
kesenangan, kemampuan untuk mengekspresikan diri seseorang, persepsi pentingnya konsekuensi negatif, yang berarti pentingnya persepsi risiko pembelian dan kemungkinan terjadinya risiko pembelian.

\section{Komitmen Pelanggan (KOM)}

Komitmen telah didefinisikan sebagai "keinginan abadi untuk mempertahankan hubungan dihargai" (Jmr, 1992). Sesuai (Morgan \& Hunt, 1994), komitmen memberikan kontribusi signifikan dalam pembentukan loyalitas dan niat perilaku dan didefinisikan dalam hubungan konsumen-brand sebagai, "saling percaya yang membutuhkan upaya untuk mempertahankan hubungan yang berkelanjutan, dengan alasan bahwa komitmen muncul ketika anggota masyarakat menghargai brand hubungan dengan anggota lain." Menurut (Beatty et al., 1988), komitmen brand didefinisikan sebagai, "lampiran emosional atau psikologis konsumen untuk brand tertentu dalam kelas produk "atas dasar definisi ini, dapat dikatakan bahwa dalam konteks komunitas online, komitmen mengacu pada sikap dan perilaku anggota masyarakat dalam komunitas brand. (Hidayanti et al., 2018) menemukan bahwa konsumen yang menunjukkan afektif komitmen kurang tertarik pada promosi pesaing.

\section{Kepercayaan Brand (KB)}

Kepercayaan brand didefinisikan sebagai "kesediaan konsumen rata-rata untuk mengandalkan kemampuan brand untuk melakukan fungsi dinyatakan" (Morris, 2001). Menurut (Luis, 2001), kepercayaan brand didefinisikan sebagai, "Perasaan keamanan yang dimiliki oleh konsumen diinteraksinya dengan brand, bahwa hal itu didasarkan pada persepsi bahwa brand dapat diandalkan dan bertanggung jawab atas kepentingan dan kesejahteraan konsumen." Kepercayaan biasanya lebih merupakan masalah ketika ada asimetri informasi dan kemungkinan oportunisme. Mengurangi asimetri informasi menghasilkan kepercayaan yang meningkat. Ini adalah janji brand dengan pelanggan brand untuk memenuhi harapan brand. Kepercayaan brand adalah sebuah barang penting yang membantu pelanggan loyal terhadap brand. Tanpa kepercayaan pada pelanggan brand tidak dapat memasukkan set loyalitas. Untuk membangun kepercayaan, penting bagi Konsumen untuk mengambil dan menilai informasi dari produk. Perusahaan dapat membangun kepercayaan emosional jika brand dapat membuktikannya brand hanya untuk pelanggan dan memenuhi harapan brand (misal brand dapat dipercaya dan ramah untuk penggunaan keluarga). Brand yang konsisten menunjukkan perilaku khusus ini (Nursalam, 2016, 2013).

\section{Loyalitas Brand (LB)}

Loyalitas telah banyak diperiksa dalam literatur pemasaran layanan (Total \& Management, 2000). Loyalitas dapat didefinisikan sebagai lampiran/perasaan terhadap brand dan perusahaan (Kotler and Gertner 2002). loyalitas brand biasanya didefinisikan sebagai respon perilaku dan sikap terhadap brand diungkapkan oleh pelanggan dari waktu ke waktu (Keller, 1993). Loyalitas dapat diidentifikasi sebagai hubungan menguntungkan bagi perusahaan dan pelanggan, sebagai konsumen setia tidak perlu mencari penyedia layanan baru (Yang \& Peterson, n.d.). Dalam komunitas brand online, pelanggan mengungkapkan loyalitas melalui kata positif brand dari word of mouth dan perilaku pembelian berulang (Hur \& Kim, 2011; Yang \& Peterson, n.d.). Menurut Hidayanti et al., 2018 mendefinisikan pelanggan loyalitas, atau loyalitas brand, sebagai "yang dipegang teguh komitmen untuk membeli kembali produk / layanan pilihan secara konsisten di masa depan, sehingga menyebabkan pembelian berulang, meskipun pengaruh situasional dan pemasaran upaya yang berpotensi menyebabkan beralih perilaku. Loyalitas pelanggan memiliki muncul sebagai salah satu yang paling penting tujuan dan kegiatan pemasaran terbukti menjadi salah satu pendorong utama laba (Afriani et al., 2019)

\section{Word of Mouth (WOM)}

Menurut Tripathi, 2018, word of mouth atau disebut informasi lisan mengacu pada, "komunikasi informal antara pihak swasta mengenai evaluasi barang dan jasa dari pada keluhan formal kepada perusahaan dan/atau personil." Informasi lisan adalah fenomena yang umum terjadi dalam studi perilaku konsumen (Kozinets et al., 2010). Situs jejaring sosial memberikan pilihan untuk menyebarkan informasi secara lisan. Jangkauan langsung media sosial untuk jutaan pengguna telah meningkatkan dispersi informasi yang luas. Perilaku yang mendukung untuk manfaat brand yang disebabkan oleh tingginya tingkat konsumen-brand identifikasi mungkin tidak menghasilkan hanya dalam peningkatan niat pembelian kembali tetapi juga dalam perilaku ekstra-peran pelanggan, seperti WOM positif (Ahearne et al, 2005; StokburgerSauer et al, 2012; Boenigk dan Helmig, 2013; Wuyts, 2007). Kami pertimbangkan ini merupakan aspek penting dari identifikasi; WOM positif, dipahami sebagai menguntungkan WOM diteruskan oleh seorang pelanggan tentang produk atau layanan tertentu, mewakili instrumen yang kuat dalam pemasaran. Sebagai WOM ditandai dengan kepercayaan yang tinggi dan jangkauan yang luas, itu dianggap menjadi instrumen yang efektif untuk membentuk konsumen sikap dan perilaku (Kalinić et al., 2019). 


\section{H1a. Hubungan keterlibatan pelanggan yang mempengaruhi secara positif dengan kepercayaan brand}

Setelah konsumen menanggapi usaha pemasaran transaksional perusahaan, brand dengan mudah terlibat dengan perusahaan itu dan mulai menjadi lebih sensitif terhadap inisiatif pemasaran relasional (Islam \& Rahman, 2016). Jika pengalaman pelanggan memuaskan, ini dapat meningkatkan kepercayaan di antara brand. Pelanggan dapat terlibat dengan komunitas brand online, yang memberikan informasi yang dapat dipercaya, benar dan tepat, dan mengarah pada penguatan kepercayaan brand terhadap brand (Jain et al., 2018). Studi sebelumnya menemukan bahwa tingkat keterlibatan yang tinggi mengakibatkan peningkatan tingkat kepercayaan pelanggan untuk brand (Purohit, 2015).

\section{H1b. hubungan komitmen customer-brand secara positif dengan kepercayaan brand}

Tingkat kepercayaan pengguna di bursa online misalnya platform media sosial adalah $e$ kepercayaan pelanggan (Luo et al., 2015). Karena ada kontak tidak langsung dengan perusahaan, pengguna online mungkin merasa berisiko untuk berinteraksi dengan brand dalam pengaturan online. Akibatnya, kepercayaan tampaknya penting untuk menciptakan komitmen (Manzoor, 2016). Sesuai penelitian, komitmen pelanggan terdiri dari kepercayaan dan keterikatan emosional. Jadi, jika sebuah perusahaan membantu konsumen untuk menurunkan risiko yang dirasakan brand, itu mendapatkan kepercayaan. Setelah sebuah perusahaan didirikan kepercayaan, lebih lanjut mencari hubungan jangka panjang dengan pelanggan (Ha, 2018). Komitmen mengacu pada situasi menciptakan hubungan konstan dengan mitra lain, bantalan pengorbanan jangka pendek untuk mempertahankan hubungan tersebut serta menjamin stabilitas hubungan (Beatty et al., 1988). Dalam sebuah penelitian, (Pitta et al., 2006) menunjukkan bagaimana pelanggan berkomitmen terhadap brand.

\section{H2a. Hubungan keterlibatan pelanggan mempengaruhi loyalitas brand.}

Untuk komunitas brand media sosial, hubungan antara keterlibatan dan loyalitas sangat penting (Islam \& Rahman, 2016). Secara berurutan, ini telah memfasilitasi brand ini menggunakan platform media sosial untuk meningkatkan keterlibatan pelanggan, dengan tujuan mendorong retensi pelanggan. Untuk keterlibatan, ada dukungan untuk mengkonfirmasi bahwa itu adalah anteseden loyalitas (Lay-hwa, 2009). Sejumlah penelitian telah membentuk hubungan langsung antara keterlibatan dan loyalitas brand (Islam \& Rahman, 2016).

H2b. Pengaruh komitmen pelanggan terhadap loyalitas brand berhubungan positif
Menurut Beatty et al., (1988) menemukan bahwa komitmen terjadi ketika seseorang mencari melalui brand sebelum membuat pilihan, sedangkan loyalitas terjadi di kemudian hari. Jadi, Beatty et al., (1988) berpendapat komitmen adalah dasar untuk pengembangan loyalitas brand. Dalam komunitas brand online, partisipasi pelanggan dan komitmen brand dapat meningkatkan nilai brand, karena dapat membantu anggota untuk memiliki pendekatan positif terhadap brand bersama dengan loyalitas brand (Kamboj \& Rahman, 2017). Akibatnya, merangsang kegiatan masyarakat, komitmen diharapkan dan menghasilkan loyalitas brand pelanggan dalam jangka panjang. Loyalitas brand memiliki kedua faktor sikap dan perilaku, dan muncul ketika komponen ini hidup berdampingan. Meskipun dalam literatur ada beberapa kebingungan tentang hubungan antara komitmen dan loyalitas, biasanya diterima bahwa komitmen sama sekali berbeda dari loyalitas dalam komitmen yang mengarah ke loyalitas

\section{H3a. Keterlibatan pelanggan berhubungan positif terhadap WOM}

Keterlibatan pelanggan mempengaruhi tingkat kekhawatiran dan minat yang terkait dengan konsumsi brand (Kuo \& Hou, 2017). Hal ini dapat disebabkan oleh fakta bahwa pelanggan yang sangat terlibat dapat menunjukkan lebih banyak kesenangan atau disonansi kognitif mungkin dalam jangka panjang dibandingkan dengan brand yang tidak terlalu terlibat (Theng, 2001). (Kenneth, 2013) menemukan bahwa pelanggan dengan tingkat keterlibatan tinggi akan menunjukkan niat tinggi untuk terlibat dalam e-word of mouth. Dalam literatur, sejumlah penelitian telah menunjukkan bahwa konsumen dengan keterlibatan tinggi cenderung terlibat dalam perilaku pasca-pembelian, misalnya perilaku word of mouth (Voyer \& Ranaweera, 2015).

\section{H3b. Komitmen pelanggan berhubungan positif terhadap WOM}

Sebagai keterikatan psikologis, konsep komitmen mengarah pada perilaku proaktif pelanggan (Bettencourt, 1997), misalnya, kata-ofâ [euro] komunikasi mulut (Lee et al., 2017). Secara khusus, ketika pelanggan berkomitmen untuk brand, branda mengidentifikasi diri branda dengan brand, dan akibatnya branda menunjukkan perilaku proaktif, misalnya, WOM positif (Prasad et al., 2017). Sejumlah ilmuwan juga telah mengidentifikasi pengaruh positif dan signifikan dari komitmen terhadap WOM (Kamboj \& Rahman, 2017).

H4: Hubungan yang mempengaruhi tingkat kepercayaan brand dengan loyalitas brand

Menurut Ou, Shih, \& Chen, 2015, kepercayaan mengurangi ketidakpastian dalam suatu 
lingkungan di mana konsumen merasa sangat rentan karena brand tahu brand dapat mengandalkan brand terpercaya. Ketika suatu brand memiliki kemampuan untuk terus memenuhi yang terbaik kepentingan dan harapan pelanggan, maka pelanggan cenderung mempercayai brand. Misalnya, pelanggan akan menyimpulkan apakah brand dapat diandalkan secara fungsional, jika kualitas dapat dipercaya atau keamanan brand sebelum brand mempertimbangkan untuk mempercayai brand tersebut (Bart et al., 2005). Akibatnya, brand yang dapat dipercaya adalah satu yang secara konsisten menepati janjinya kepada pelanggan melalui atasannya kinerja, karenanya menjamin loyalitas brand pelanggan dalam proses (Chiou dan Droge, 2006). Dengan demikian, kepercayaan brand adalah hasil dari proses pelanggan yang cermat dan dipikirkan dengan baik mengenai brand dan dapat dipandang sebagai pengungkit keandalan dan kredibilitasnya (Morris, 2001). Oleh karena itu, dapat dikatakan bahwa semakin tinggi tingkat kepercayaan brand pelanggan, semakin tinggi loyalitas brand pelanggan yang diharapkan. Bukti empiris sebelumnya telah menemukan hubungan positif antara kepercayaan brand dan loyalitas brand (mis. (Robert \& Shelby, 1994, 1994; Doney dan Cannon, 1997; Chiou dan Droge, 2006) dan karenanya brand kepercayaan dapat diharapkan mengarah pada loyalitas brand dalam kasus Afrika Selatan.

\section{H5: Hubungan yang mempengaruhi tingkat kepercayaan brand dengan WOM}

R. B. Kim et al., (2015) menunjukkan bahwa Word-of-Mouth adalah faktor kunci dalam keluarga yang mengambil keputusan membeli produk dan makanan. (Khan \& Rahman, 2016) menemukan bahwa sekitar $60 \%$ pelanggan baru mengkonsumsi dalam sebuah perusahaan dipengaruhi oleh Word-of-Mouth. Word-of-Mouth adalah tatap muka dan non-komersial perilaku komunikasi di antara orang-orang untuk mempengaruhi evaluasi konsumen dan niat konsumsi melalui pertukaran informasi dari produk atau layanan tertentu (Parra et al. 2011). Khadim et al., (2018) menyebutkan bahwa Brand Kepercayaan didirikan berdasarkan reputasi perusahaan, dan reputasi yang menguntungkan dapat diperkuat kepercayaan konsumen serta meningkatkan loyalitas atau niat beli. Ini mengungkapkan bahwa Word-ofMouth akan melakukannya mempengaruhi kepercayaan konsumen untuk suatu perusahaan dan secara tidak langsung akan mempengaruhi niat perilaku (Handini \& Ruswanti, 2016). Handini \& Ruswanti, (2016) juga menunjukkan efek positif dari Word-of-Mouth pada persepsi konsumen nilai, yang selanjutnya akan mempengaruhi Kepercayaan Brand, bahwa Word-of-Mouth dapat memengaruhi Kepercayaan Brand.

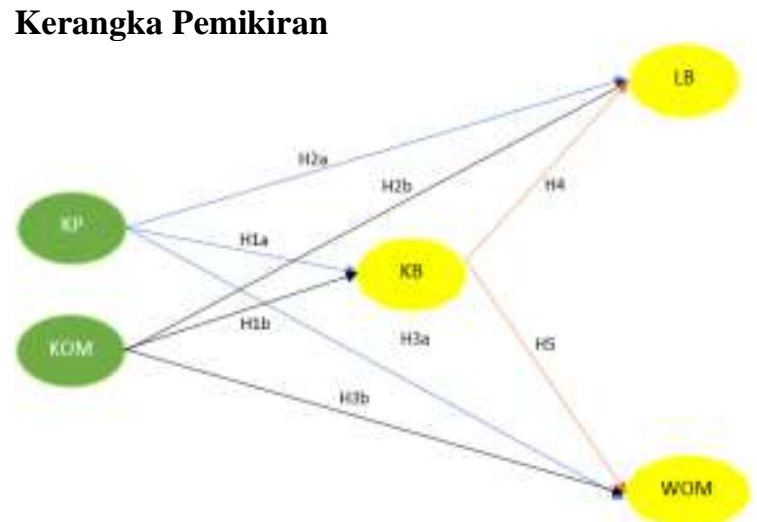

Gambar 1. Kerang Pemikiran

\section{Metode Penelitian}

\section{Desain Penelitian}

Kerangka pengambilan sampel untuk penelitian ini adalah pemuda (mahasiswa/karyawan), karena kelompok ini mewakili pengguna internet aktif di Indonesia (Internet dan Mobile Association of India (IAMAI), 2015). Pengumpulan sampel ini menggunakan survei berbasis web. Responden diminta untuk menjawab instrumen kuisioner berdasarkan persepsi brand mengenai komunitas online yang menjadi bagian dari brand. Untuk tujuan ini, peneliti mengumpulkan data kuantitatif dengan memberikan undangan untuk berpartisipasi dalam kuisioner online dengan hyperlink ke kuesioner berbasis web (menggunakan Google Docs/Form) kepada mahasiswa dan karyawan di Jakarta Barat. Untuk memastikan kelayakan responden, awalnya pertanyaan skrining diajukan dari responden bahwa apakah brand telah berlangganan, menyukai atau bergabung dengan komunitas brand online di media sosial.

Pretesting dilakukan dengan melakukan penyebaran kuisioner dilakukan pada mahasiswa dan karyawan yang bekerja di perusahaan yang berbeda. Secara total, 50 mahasiswa dan karyawan yang ada di Jakarta Barat yang menggunakan produk Nature Republic. Komentar peserta dibantu dalam penyempurnaan instrumen sehubungan dengan format, kejelasan, panjang dan keterbacaannya. Sebanyak 221 tanggapan diperoleh dari survei berbasis web, 195 tanggapan efektif dianggap valid yang dianalisis menggunakan statistic analisis software (SPSS 16.0). Sebagian besar responden yang belum menikah milik kelompok usia antara 21 dan 25 tahun, mayoritas responden menghabiskan 30 menit-2 jam di situs media sosial. Studi sebelumnya juga mengungkapkan bahwa orang dewasa muda adalah pengguna web yang paling aktif (Kaur, 2016; Park and Kim, 2014). Dengan demikian, data bersifat representatif karena mayoritas pengguna internet dan media sosial termasuk dalam kelompok usia 18-30 tahun (IAMAI, 2015). Penelitian ini memiliki ukuran sampel 195 yang diikuti sesuai 
pedoman Hair dkk. (2014), yang menyatakan bahwa "Ukuran sampel minimum - 100: Model yang berisi lima atau lebih sedikit konstruksi, masing-masing dengan lebih dari tiga item (variabel yang diamati. Dengan demikian, ukuran sampel menganggap tepat untuk analisis data dengan parsial setidaknya kuadrat berbasis pemodelan persamaan struktural (PLS-SEM).

\section{Kuisioner dan Pengukuran}

Dalam penelitian ini, semua item skala diukur pada skala Likert lima titik berlabuh dengan 1 = sangat tidak setuju dan 5 = sangat setuju. Empat item yang diadaptasi dari skala yang dikembangkan sebelumnya digunakan untuk mengukur keterlibatan pelanggan (Islam dan Rahman, 2016) dan diubah sesuai dengan dasar studi percontohan. Dalam konseptualisasi kepuasan pelanggan, makalah ini menggunakan tiga item untuk mengevaluasi kepuasan pelanggan yang dipinjam dari Hajli $d k k$. (2017). Komitmen ini dioperasionalisasikan dengan enam item seperti yang disarankan oleh Aaker $d k k$. (2008) dan Kuo dan Feng (2013) timbangan langkah-langkah kepercayaan brand diadaptasi dari Chaudhuri dan Holbrook (2001) dan Kang et al. (2014), empat item dipinjam dan diubah berdasarkan studi percontohan. Item ini mengukur keandalan, integritas dan kepercayaan brand dalam komunitas online. Loyalitas brand dioperasionalisasi dengan tiga item seperti yang disarankan oleh penelitian sebelumnya (Chaudhuri dan Holbrook, 2001; Laroche et al., 2012; Zheng et al. , 2015). Skala untuk dari mulut ke mulut dipinjam dari Choi dan Choi (2014), Hur dkk. (2011) dan Zeithaml dkk. (1996).

Analisis penelitian ini menggunakan pemodelan jalur PLS-SEM diterapkan untuk menguji hipotesis yang diajukan dan untuk memvalidasi langkahlangkah tersebut. Metode ini telah digunakan sebagai fenomena yang diteliti adalah yang terbaru dan penelitian bermaksud untuk generasi teori daripada konfirmasi teori (Urbach dan Ahlemann, 2010). Selain itu, pendekatan ini tidak memerlukan distribusi normal, seperti yang diperlukan dalam pendekatan berbasis kovarians (Hair et al., 2014). Ini bekerja dengan baik dengan ukuran sampel kecil, dan terakhir pendekatan PLS mencakup langkahlangkah formatif dan reflektif (Rambut et al., 2014) . Mengingat sifat pengembangan teori studi dan ukuran sampel kecil, PLS-SEM adalah alat multivariat yang tepat untuk menguji model struktural.

\section{Hasil dan Pembahasa Demografi Responden}

Dari 195 responden perempuan, usia dikebanyakan responden yaitu berkisar 19-25 tahun sebanyak $73,3 \%$ dan $26-32$ tahun $26,7 \%$ dengan pendidikan terakhir $86,9 \%$ sarjana dan $13,1 \%$ adalah karyawan.

\section{Uji Validitas dan Reliability}

Berdasarkan uji validitas diketahui bahwa nilai dari setiap item pernyataan dalam kuisioner sudah valid dengan r-hitung > r-tabel. Uji reliabilitas juga menunjukkan bahwa nilai Cronbach Alpha dari setiap variabel lebih besar dari 0,60 sehingga dapat disimpulkan bahwa kuisioner dalam penelitian ini reliabel. Lampiran 1. Uji Validitas dan Reliabilitas

\begin{tabular}{lrc}
\hline & Uji Validitas & Uji Reliabilitas \\
A1 & 0.750 & 0.772 \\
A2 & 0.886 & \\
A3 & 0.845 & 0.860 \\
\hline B1 & 0.750 & \\
B2 & 0.775 & \\
B3 & 0.780 & \\
B4 & 0.771 & \\
B5 & 0.807 & 0.729 \\
B6 & 0.724 & \\
\hline C1 & 0.676 & \\
C2 & 0.787 & 0.706 \\
C3 & 0.769 & \\
C4 & 0.742 & \\
\hline D1 & 0.775 & 0.883 \\
D2 & 0.810 & \\
D3 & 0.824 & \\
\hline E1 & 0.864 & \\
E2 & 0.923 & \\
E3 & 0.913 & \\
\hline
\end{tabular}

\section{Uji Hipotesis}

Karena penelitian ini menggunakan program Lisrel (Linier Struktural Relationship) yang merupakan paket program statistic untuk Structural Equation Model (SEM), berikut dibawah diagram hasil hipotesis T-Value : 


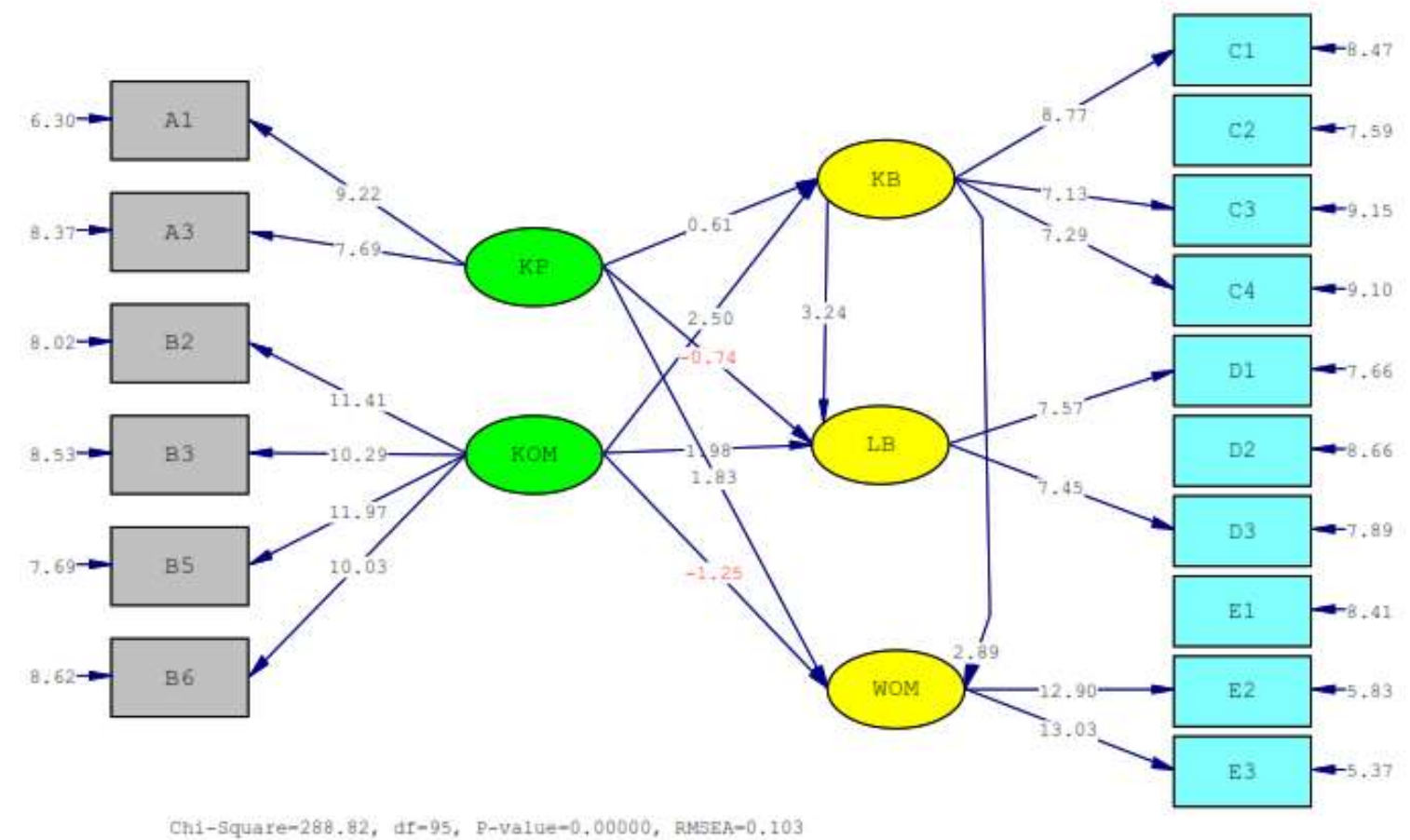

Pada instrument pertanyaan dalam kuisioner ada beberapa pertanyaan yang dihilangkan saat uji hipotesis yang menggunakan analisis statistik SEM hal ini dikarenakan data tersebut kurang baik seperti untuk pertanyaan A2 untuk hipotesis keterlibatan pelanggan serta B1 dan B4 untuk hipotesis komitmen pelanggan sehingga harus dihilangkan dalam pengujian.

H1a : Hipotesis H1a menyatakan pengaruh keterlibatan pelanggan terhadap kepercayaan brand signifikan, dengan koefisien jalur pada hubungan ini sebesar 0,17 dengan t-value sebesar 0,61. Hasil ini sejalan dengan Jain, Kamboj, Kumar, \& Rahman, 2018 yang menjelaskan bahwa keterlibatan pelanggan berpengaruh positif terhadap kepercayaan brand yaitu dengan nilai t-value sebesar 0.24.

H1b : Hipotesis H1b menyatakan pengaruh komitmen pelanggan terhadap kepercayaan brand signifikan yaitu dengan koefisien jalur pada hubungan sebesar 0,68 dan t-value sebesar 2,50. Hasil tersebut sejalan dengan Jain, Kamboj, Kumar, \& Rahman, 2018 dengan nilai t-value 0,37. Hasil tersebut menyimpulkan bahwa komitmen pelanggan berpengaruh positif terhadap kepercayaan brand H2a : Hipotesis $\mathrm{H} 2 \mathrm{a}$ menyatakan pengaruh keterlibatan pelanggan dengan mediasi kepercayaan brand dapat menurunkan loyalitas pelanggan dengan koefisien jalur pada hubungan ini sebesar $-0,18$ dengan t-value sebesar -0,74. Hasil ini tidak sejalan dengan Jain, Kamboj, Kumar, \& Rahman, 2018 yang menjelaskan bahwa keterlibatan pelanggan berpengaruh positif terhadap loyalitas brand dengan dimediasi kepercayaan brand yaitu dengan nilai tvalue sebesar 0.31. Hal tersebut menunjukkan ada beberapa data kuisioner kurang baik
H2b : Hipotesis $\mathrm{H} 2 \mathrm{~b}$ menyatakan pengaruh komitmen pelanggan dengan mediasi kepercayaan brand dapat berpengaruh terhadap loyalitas pelanggan, dengan koefisien jalur pada hubungan ini sebesar 0,49 dengan t-value sebesar 1,98. Hasil tersebut sejalan dengan Jain, Kamboj, Kumar, \& Rahman, 2018 dengan nilai t-value 0,24. Hasil tersebut menyimpulkan bahwa komitmen pelanggan dengan mediasi kepercayaan brand dapat meningkat kan loyalitas pelanggan.

H3a : Hipotesis H3a menyatakan pengaruh keterlibatan pelanggan dengan dimediasi kepercayaan brand terhadap WOM dapat berpengaruh positif dengan koefisien jalur pada hubungan ini sebesar 0,72 dengan t-value sebesar 1,83. Hasil ini sejalan dengan Jain, Kamboj, Kumar, \& Rahman, 2018 dengan nilai t-value 0.19. Hasil tersebut menyimpulkan bahwa keterlibatan pelanggan dengan mediasi kepercayaan brand dapat meningkatkan WOM.

H3b : Hipotesis $\mathrm{H} 3 \mathrm{~b}$ menyatakan pengaruh komitmen pelanggan dengan dimediasi kepercayaan brand tidak mempengaruhi WOM dengan koefisien jalur pada hubungan ini sebesar $-0,54$ dengan $\mathrm{t}$-value sebesar -1,25. Hasil ini tidak sejalan dengan Jain, Kamboj, Kumar, \& Rahman, 2018 yang menyatakan nilai $t$-value 0.33 . Hal tersebut menunjukkan ada beberapa data kuisioner kurang baik

H4 : Hipotesis H4 menyatakan kepercayaan brand berpengaruh langsung terhadap loyalitas brand, dengan koefisien jalur pada hubungan ini sebesar 0.63 dengan t-value sebesar 3,24. Hasil ini sejalan dengan Jain, Kamboj, Kumar, \& Rahman, 2018 dengan nilai $t$-value 0,64 sehingga dapat disimpulkan bahwa data penelitian mendukung 
hipotesis H4, kepercayaan brand berpengaruh terhadap loyalitas brand.

H5 : Hipotesis H5 menyatakan kepercayaan brand berpengaruh langsung terhadap WOM, dengan koefisien jalur pada hubungan ini sebesar 0,63 dan $t$ value sebesar 2,89. Hasil ini sejalan dengan Jain, Kamboj, Kumar, \& Rahman, 2018 dengan nilai $t$ value 0,80 sehingga dapat disimpulkan bahwa data penelitian mendukung hipotesis $\mathrm{H} 5$, kepercayaan brand berpengaruh terhadap WOM.

Tabel 1. Hasil hipotesis diagram koefisien

\begin{tabular}{clccc}
\hline $\begin{array}{c}\text { Hip } \\
\text { otesi } \\
\text { S }\end{array}$ & \multicolumn{1}{c}{$\begin{array}{c}\text { Pernyataan } \\
\text { Hipotesis }\end{array}$} & $\begin{array}{c}\text { Standar } \\
\text { dized } \\
\text { Solution }\end{array}$ & $\begin{array}{c}\text { T- } \\
\text { Value }\end{array}$ & Ket \\
\hline H1a & $\begin{array}{l}\text { Keterlibatan } \\
\text { pelanggan tidak } \\
\text { mempengaruhi } \\
\text { brand } \text { kepercayaan }\end{array}$ & 0,17 & 0,61 & $\begin{array}{c}\text { Diteri } \\
\text { ma }\end{array}$ \\
& $\begin{array}{l}\text { Komitment } \\
\text { pelanggan } \\
\text { mempengaruhi }\end{array}$ & 0,68 & 2,50 & Diteri \\
ma
\end{tabular}

\section{Kesimpulan}

Berdasarkan hasil penelitian yang telah dilakukan mengenai memeriksa hubungan customer brand dalam komunitas brand platform media sosial produk Nature Republic di Jakarta Barat terhadap 195 responden yang diperoleh dari mahasiswa dan karyawan yang menggunakan produk Nature Republic dapat diambil beberapa kesimpulan yang diharapkan dapat memberikan jawaban terhadap permasalahan yang dirumuskan dalam penelitian ini, yaitu sebagai berikut: Berdasarkan hasil statistic Structural Equation Model (SEM) yang menggunakan program Lisrel (Linier Struktural Relationship) kepercayaan brand berpengaruh positif terhadap customer brand (Keterlibatan dan Komitmen), loyalitas brand dan word of mouth (WOM) pelanggan dalam komunitas brand platform media sosial. Namun ada beberapa data pengisian kuisioner yang kurang baik seperti pertanyatan A2 terkait hipotesis keterlibatan pelanggan serta B1 dan B4 terkait hipotesis komitmen pelanggan. Dari semua data penelitian yang disajikan dapat disimpulakan bahwa semakin tingginya kepercayaan brand produk Nature Republic akan meningkatkan penjualan dari produk tersebut.

\section{Referensi}

Afriani, R., Indradewa, R., \& Syah, T. Y. R. (2019). Brand Communications Effect, Brand Images , and Brand Trust Over Loyalty Brand Building at PT Sanko Material Indonesia. 3(3), 44-50.

Aladwani, A. M. (2014). The 6As model of social content management. International Journal of Information Management, 34(2), 133-138. https://doi.org/10.1016/j.ijinfomgt.2013.12.00 4

Badan Pusat Statistik. (n.d.). Retrieved July 14, 2021, from https://www.bps.go.id/pressrelease/2021/01/21 /1854/hasil-sensus-penduduk-2020.html

Beatty, S. E., Homer, P., \& Kahle, L. R. (1988). The involvement-commitment model: Theory and implications. Journal of Business Research, 16(2), 149-167. https://doi.org/10.1016/01482963(88)90039-2

Bennett, R., Härtel, C. E. J., \& McColl-Kennedy, J. R. (2005). Experience as a moderator of involvement and satisfaction on brand loyalty in a business-to-business setting 02-314R. Industrial Marketing Management, 34(1), 97107. https://doi.org/10.1016/j.indmarman.2004.08.0 03

Bettencourt, L. A. (1997). Customer voluntary performance: Customers as partners in service delivery. Journal of Retailing, 73(3), 383-406. https://doi.org/10.1016/S0022-4359(97)900245

Chinomona, R. (2016). Brand communication, brand image and brand trust as antecedents of brand loyalty in Gauteng Province of South Africa. African Journal of Economic and Management Studies, 7(1), 124-139. https://doi.org/10.1108/AJEMS-03-2013-0031

Dwi Karyati, A. M. (2019). Pengaruh Brand Image Terhadap Minat Beli Ulang Di Polos Bandung. 5(2), 652-659. http://repository.unpas.ac.id/id/eprint/41574

Ha, Y. (2018). Effects of online brand community on value creation practices: Mediating effects of community loyalty. Journal of Business and Retail Management Research, 12(3), 59-78. https://doi.org/10.24052/jbrmr/v12is03/art-06 
Handini, S., \& Ruswanti, E. (2016). Effect of Service Quality Word of Mouth With Mediation Patient Satisfaction and. Conference on Management and Behavioral Studies, 595-603.

Hidayanti, I., Nuryakin, \& Farida, N. (2018). A study on brand commitment and brand trust towards brand loyalty of branded laptop in Indonesia. Journal of Business and Retail Management Research, 12(3), 270-278. https://doi.org/10.24052/jbrmr/v12is03/art-25

Hur, W., \& Kim, M. (2011). Building brand loyalty through managing brand community commitment. $49(7), \quad 1194-1213$. https://doi.org/10.1108/00251741111151217

Islam, J. U., \& Rahman, Z. (2016). The transpiring journey of customer engagement research in marketing. https://doi.org/10.1108/MD-012016-0028

Jain, N. K. (2018). Examining consumer-brand relationships on social media platforms. 36(1), 63-78. https://doi.org/10.1108/MIP-05-20170088

Jain, N. K., Kamboj, S., Kumar, V., \& Rahman, Z. (2018). Examining consumer-brand relationships on social media platforms. Marketing Intelligence and Planning, 36(1), 63-78. https://doi.org/10.1108/MIP-05-20170088

Jmr, R. (1992). Relationships Between Providers and Users of Market Research : The ...

Kalinić, Z., Marinković, V., Djordjevic, A., \& Liebana-Cabanillas, F. (2019). What drives customer satisfaction and word of mouth in mobile commerce services? A UTAUT2-based analytical approach. Journal of Enterprise Information Management, 33(1), 71-94. https://doi.org/10.1108/JEIM-05-2019-0136

Kamboj, S., \& Rahman, Z. (2017). Understanding customer participation in online brand communities: Literature review and future research agenda. Qualitative Market Research, 20(3), 306-334. https://doi.org/10.1108/QMR08-2016-0069

Keller, K. L. (1993). Conceptualizing, Measuring, and Managing Customer-Based Brand Equity. Journal of Marketing, 57(1), 1. https://doi.org/10.2307/1252054

Kemenperin: Industri Kosmetik Nasional Tumbuh 20\%. (n.d.). Retrieved July 14, 2021, from https://kemenperin.go.id/artikel/18957/Industri -Kosmetik-Nasional-Tumbuh-20

Kemenperin: Perubahan Gaya Hidup Dorong Industri Kosmetik. (n.d.). Retrieved July 14, 2021, from https://kemenperin.go.id/artikel/21460/Peruba han-Gaya-Hidup-Dorong-Industri-Kosmetik
Kenneth, F. (2013). WORD OF MOUTH: WHAT WE KNOW AND WHAT WE HAVE YET TO LEARN.

Khadim, R. A., Hanan, M. A., Arshad, A., Saleem, N., \& Khadim, N. A. (2018). Revisiting antecedents of brand loyalty: Impact of perceived social media communication with brand trust and brand equity as mediators. Academy of Strategic Management Journal, 17(1).

Khan, I., \& Rahman, Z. (2016). E-tail brand experience's influence on e-brand trust and ebrand loyalty: The moderating role of gender. International Journal of Retail and Distribution Management, 44(6), 588-606. https://doi.org/10.1108/IJRDM-09-2015-0143

Kim, R. B., Yoon, D. H., \& Yan, C. (2015). Effects of brand experience on brand trust, brand satisfaction \& brand loyalty: Building spa brands in South korea. Actual Problems of Economics, 168(6), 182-189.

Kim, S. H., \& Lee, S. (Ally). (2017). Promoting customers' involvement with service brands: evidence from coffee shop customers. Journal of Services Marketing, 31(7), 733-744. https://doi.org/10.1108/JSM-03-2016-0133

Kotler, P., \& Gertner, D. (2002). Country as brand, product, and beyond: A place marketing and brand management perspective. Journal of Brand Management, 9(4), 249-261. https://doi.org/10.1057/palgrave.bm.2540076

Kozinets, R. V, Valck, K. De, Wojnicki, A. C., \& Wilner, S. J. S. (2010). Networked Narratives : Understanding Word-of-Mouth. 74(March), 71-89.

Kuo, Y. F., \& Hou, J. R. (2017). Oppositional brand loyalty in online brand communities: Perspectives on social identity theory and consumer-brand relationship. Journal of Electronic Commerce Research, 18(3), 254268.

Laurent, G., \& Kapferer, J.-N. (1985). Measuring Consumer Involvement Profiles. Journal of Marketing Research, 22(1), 41. https://doi.org/10.2307/3151549

Lay-hwa, J. (2009). THE PROCESS OF CUSTOMER ENGAGEMENT: A CONCEPTUAL FRAMEWORK.

Lee, W. I., Cheng, S. Y., \& Shih, Y. T. (2017). Effects among product attributes, involvement, word-of-mouth, and purchase intention in online shopping. Asia Pacific Management Review, 22(4), 223-229. https://doi.org/10.1016/j.apmrv.2017.07.007

Lisle, D. (2016). Off-duty resilience: Reorienting tourism, leisure, and recreation in the US Army BOSS Program. American Quarterly, 
68(3), https://doi.org/10.1353/aq.2016.0061

Luis, J. (2001). Brand trust in the context of consumer loyalty.

Luo, N., Zhang, M., \& Liu, W. (2015). The effects of value co-creation practices on building harmonious brand community and achieving brand loyalty on social media in China. Computers in Human Behavior, 48, 492-499. https://doi.org/10.1016/j.chb.2015.02.020

Manzoor, A. (2016). Is There a Link between Facebook Use and Student's Emotions? FIIB Business Review, 5(2), 71-77. https://doi.org/10.1177/2455265820160208

Mollen, A., \& Wilson, H. (2010). Engagement, telepresence and interactivity in online consumer experience: Reconciling scholastic and managerial perspectives. Journal of Business Research, 63(9-10), 919-925. https://doi.org/10.1016/j.jbusres.2009.05.014

Morgan, R. M., \& Hunt, S. D. (1994). The Commitment-Trust Theory of Relationship Marketing. Journal of Marketing, 58(3), 20. https://doi.org/10.2307/1252308

Morris, B. (2001). The chain of effects from brand trust and brand affect to brand performance: The role of brand lo ...

Nisar, T. M., \& Whitehead, C. (2016). Brand interactions and social media: Enhancing user loyalty through social networking sites. Computers in Human Behavior, 62, 743-753. https://doi.org/10.1016/j.chb.2016.04.042

Nursalam, 2016, metode penelitian. (2013). 済無No Title No Title. Journal of Chemical Information and Modeling, 53(9), 1689-1699. https://doi.org/10.1017/CBO9781107415324.0 04

Ou, W. M., Shih, C. M., \& Chen, C. Y. (2015). Effects of ethical sales behaviour on satisfaction, trust, commitment, retention and words-of-mouth. International Journal of Commerce and Management, 25(4), 673-686. https://doi.org/10.1108/IJCoMA-04-20130040

Pitta, D., Franzak, F., \& Fowler, D. (2006). A strategic approach to building online customer loyalty: Integrating customer profitability tiers. Journal of Consumer Marketing, 23(7), 421429.

https://doi.org/10.1108/07363760610712966

Prasad, S., Gupta, I. C., \& Totala, N. K. (2017). Social media usage, electronic word of mouth and purchase-decision involvement. AsiaPacific Journal of Business Administration, 9(2),

$134-145$ https://doi.org/10.1108/APJBA-06-2016-0063

Purohit, H. C. (2015). Examining and Exploring the Relationships Between Customer Satisfaction and Customer Loyalty. Delhi Business Review $\square, \quad 16(2)$. http://www.delhibusinessreview.org/V16n2/db r_v16n2d.pdf

Rapp, A., \& Beitelspacher, L. S. (2013). Understanding social media effects across seller, retailer, and consumer interactions. 547-566. https://doi.org/10.1007/s11747-0130326-9

Theng, G. (2001). Individual and situational factors influencing negative word-of-mouth behaviour.

Total, K., \& Management, Q. (2000). The relationship between customer satisfaction and loyalty: Cross-industry differences. 4-6.

Tripathi, G. (2018). Customer Satisfaction and Word of Mouth Intentions: Testing the Mediating Effect of Customer Loyalty. Journal of Services Research, 17(2), 1-16.

Users, I. T. O. (n.d.). Microfilms International.

Voyer, P. A., \& Ranaweera, C. (2015). The impact of word of mouth on service purchase decisions: Examining risk and the interaction of tie strength and involvement. Journal of Service Theory and Practice, 25(5), 636-656. https://doi.org/10.1108/JSTP-04-2014-0070

Yang, Z., \& Peterson, R. T. (n.d.). Customer Perceived Value, Satisfaction, and Loyalty: 21(October 2004), 799-822. https://doi.org/10.1002/mar.20030 